\title{
Improvement Efficiency of Organic Manure and Gypsum on Properties of New Reclaimed Soil Cropped with Sugar Beet As Affected by Blending Irrigation Water at Bats Mixing Station in Fayoum, Egypt
}

\author{
Abdel-Nasser A. A. Abdel-Hafeez ${ }^{1}$
}

\begin{abstract}
A field experiment was conducted during agricultural growing season of 2005-2006 on three sites of newly reclaimed loamy sand soils irrigated with low qualities of irrigation waters derived from Bahr Wahbey water, Bats drainage water and blending water of Bats mixing station at Fanos Village, Tamia district, Fayoum Governorate. The experimental treatments were designed to study the negative effects of the used low water qualities on both the newly reclaimed soils and sugar beet characteristics as well as to clarify the optimized rate of the used farmyard manure (FYM) which was integrated with local gypsum as soil amendments to alleviate the hazardous effects of these irrigation water on soil properties and both sugar beet yield and its quality. The applied rates of the tested soil amendments were $0,15,30$ and $45 \mathrm{~m}^{3}$ FYM /fed and $0,2,4$ and 6 ton gypsum/fed, and thoroughly mixed with the tested soil plots before planting sugar beet, which their root yields were harvested after 180 days from planting. Soil physical and chemical properties were determined for each of the studied treatments after sugar beet harvest, thereafter, root yield and its quality were also measured

The obtained results showed that the short-term use of the low water qualities for irrigating sugar beet plants left their negative footprints on the tested soil properties as well as root yield and its quality parameters under study, particularly in case of soil plots received Bats saline drainage water. However, the values of soil bulk density, hydraulic conductivity, available water were tended to decrease vs. an increase in each of soil pH, ECe and ESP, besides a noticeable reduction in the vegetative growth, root yield and its quality parameters of sugar beet, taking into consideration that the changes in the majority of these characteristics reached the level of significance. On the other hand, application of FYM and local gypsum as solely or together was associated with an ameliorated effect on each of the aforementioned characteristics concerned with either the experimental soil or sugar beet, with a significant positive effect being at the combined treatments.
\end{abstract}

That was true, since the treatments of $\left(30 \mathrm{~m}^{3}\right.$ FYM $/$ fed +4 ton gypsum /fed) and $\left(45 \mathrm{~m}^{3}\right.$ FYM /fed +6 ton gypsum /fed) gave the best improvement efficiencies on root yield of +43.90 and $+44.60 \%$ with site $I ;+45.80$ and +46.50 with site II and +21.10 and +21.5 with site III over the control treatment, respectively, but the difference between these two treatments in the studied characteristics of both soil and plant didn't reach the level of significance.
Such ameliorated effects in soil properties were positively reflected on root yield and its quality of the grown sugar beet plants. Thus, it is noteworthy to mention that the treatment of $\left(30 \mathrm{~m}^{3} \mathrm{FYM} / \mathrm{fed}+4\right.$ ton gypsum/fed) is considered the best one from the economical point of view. So that, it could be recommended that organic manure integrated with gypsum should be applied to alleviate the hazardous effects of long-term use of low qualities of irrigation waters on soil properties and to achieve sustainable root yield of sugar beet.

Key words: Low qualities of irrigation water, Properties of Fayoum soils, Soil amendments, Sugar beet crop and Blending water,

\section{INTRODUCTION}

The Egyptian strategy for horizontal and vertical expansion in agriculture needs more water resources than the currently exists. The Nile River is the main source of irrigation water as total supply to Fayoum Governorate is about $2.3 \times 10^{9} \mathrm{~m}^{3} /$ year, of which $66 \%$ consumed by crops evapotranspiration, $3 \%$ by open water surface evaporation, $11 \%$ drainage to Wadi Rayan lakes and $20 \%$ drainage to Lake Qarun (Hegazi, 1999 and Van-Zov and Jeans, 1992). In facts, Ministry of irrigation (1977) estimated the total annual discharge of drainage water in all agricultural area of Egypt by more than 16 billion cubic meters. It was suggested that a part of this drainage water could be reused for irrigation purposes to partially satisfy the crops demand to irrigation water. According to the national plan target in Egypt, the official drainage water reuse in all of the country, as targeted by the years 2007 and 2017 are $6591 \times 10^{6}$ and $8631 \times 10^{6} \mathrm{~m}^{3} /$ year, respectively (National Water Resources Plan, 1999). Meanwhile, of which 396 $\mathrm{x} 10^{6} \mathrm{~m}^{3} /$ year are targeted for reuse at the year 2007 and up to 2017 for Fayoum Governorate.

The newly reclaimed soils in Fayoum area are still suffering from shortage in irrigation water, especially at the end tails of irrigation canals during the summer season. This shortage in irrigation water could be partly balanced by the reuse of drainage water after mixing with water from Bahr Wahbey canal. The composition and concentration of drainage waters in Fayoum vary from one location to another as well as during the months of the year (El-Banna et al., 1982 and Shehata

\footnotetext{
${ }^{1}$ Soil and Water Department, Faculty of Agriculture, Fayoum

University, 63514 Fayoum, Egypt

Received March11, 2009, Accepted March30, 2009
} 
et al., 1983). El Shakweer and Abdel Hafeez (2008) showed that the salinity levels of drainage waters of some drains in Fayoum are generally ranged between "high" to "very high", denote a salinity hazardous as well as such waters are categorized as "low-medium sodicity hazardous". Actually, at the Bats mixing station, waters from Bahr Wahbey are mixed with waters from Bats drain to produce the blending water at Bats mixing station. At this area, some farmers use waters from Bahr Wahbey, Bats drain directly and/or those produced from the Bats mixing station. Total salts of waters from Bahr Wahbey, Bats drain and Bats mixing station are $614.4,1292.8$ and $1132.8 \mathrm{mg} \mathrm{L}^{-1}$, respectively (El Shakweer and Abdel Hafeez, 2008). The used waters either from Bats mixing station or from the Bats drain before mixing are categorized between "high" to "very high" of salinity hazardous and categorized as "low-medium sodicity hazardous".

It is well known that gypsum is a source of calcium ions and the exchangeable sodium percentage (ESP) can be lowered by replacing the sodium ions that adsorbed to the surface of soil particles with calcium ions (Bauder, 2001). Application of organic materials (organic manure) as a soil amendments is of a direct relevance that it has drastic effects on some soil properties which reflect positively on the existed crops, in particular, their growth, yield and quality (Sandhya et al., 1994; Celik et al., 2004; Ertli et al., 2004 and Abdel Hafeez, 2008).

Sugar beet crop is one of the most important sugar crops throughout most countries in the World. The crop has been grown under wide range of climates, soils and environmental conditions. The crop characterized by early ripening, long growing season and tolerance to drought and salinity (Abdel Razik, 2005). Different efforts aimed to introduce more areas to sugar beet cropping in Fayoum, as the soil types, irrigation waters and climatic factors are suitable to such crop.

The main purpose of the present work is to study the improvement efficiency of some soil amendments (i.e., gypsum and organic manure (FYM)) added at different rates on some soil physical, chemical properties, root yield and quality of sugar beet crop under the applied different qualities of irrigation waters derived from Bahr Wahbey, waters, Bats drainage water and blending waters produced from Bats mixing station for irrigation purposes aiming to introduce the best rates of soil amendments application with each of the tested three qualities of waters.

\section{MATERIALS AND METHODS}

A field experiment was conducted during agricultural growing season of 2005-2006 on three newly reclaimed loamy sand soils irrigated with low qualities of irrigation waters derived from Bahr Wahbey water, Bats drainage water and blending water at Fanos

Table 1. Initial soil properties of the studied three sites at a surface depth of $(0-60 \mathrm{~cm})$

\begin{tabular}{|c|c|c|c|}
\hline Soil characteristics & Soil site (I) & Soil site (II) & Soil site (III) \\
\hline \multicolumn{4}{|l|}{ Particle size distribution \%: } \\
\hline$\overline{\text { Sand }}$ & 82.10 & 82.20 & 82.10 \\
\hline Silt & 10.50 & 10.70 & 11.30 \\
\hline Clay & 7.40 & 7.10 & 6.60 \\
\hline Textural class & Loamy sand & Loamy sand & Loamy sand \\
\hline Bulk density $\left(\mathrm{g} \mathrm{cm}^{-3}\right)$ & 1.50 & 1.49 & 1.48 \\
\hline Hydraulic conductivity $\left(\mathrm{cm} \mathrm{h}^{-1}\right)$ & 11.95 & 12.52 & 12.10 \\
\hline Available water $\%$ & 6.60 & 6.70 & 6.00 \\
\hline $\mathrm{CaCO}_{3} \%$ & 4.50 & 4.42 & 4.19 \\
\hline Organic matter $\%$ & 0.09 & 0.10 & 0.11 \\
\hline Gypsum \% & 0.09 & 0.14 & 0.10 \\
\hline CEC (C mole kg ${ }^{-1}$ soil) & 8.10 & 7.70 & 7.20 \\
\hline ESP & 7.79 & 7.46 & 6.71 \\
\hline Soil pH & 7.94 & 7.97 & 7.96 \\
\hline $\operatorname{ECe}\left(\mathrm{dS} . \mathrm{m}^{-1}\right)$ & 3.95 & 4.22 & 4.00 \\
\hline \multicolumn{4}{|c|}{ Chemical analysis of soil paste extract (ions in $m_{\text {mole }} L^{-1}$ ): } \\
\hline $\mathrm{Ca}^{++}$ & 11.85 & 12.66 & 12.00 \\
\hline $\mathrm{Mg}^{++}$ & 9.68 & 10.34 & 9.80 \\
\hline $\mathrm{Na}^{+}$ & 17.78 & 18.99 & 18.00 \\
\hline $\mathrm{K}^{+}$ & 0.19 & 0.20 & 0.20 \\
\hline $\mathrm{CO}_{3}^{--}$ & 0.00 & 0.00 & 0.00 \\
\hline $\mathrm{HCO}_{3}^{-}$ & 1.98 & 2.11 & 2.00 \\
\hline $\mathrm{Cl}^{-}$ & 33.58 & 35.87 & 34.00 \\
\hline $\mathrm{SO}_{4}^{--}$ & 4.31 & 4.60 & 4.36 \\
\hline
\end{tabular}


Village, Tamia district, Fayoum Governorate. Soils of the studied three sites are surveyed as newly reclaimed ones. The first soil site (I) irrigated from Bahr Wahby water; the second site (II) irrigated with saline drainage waters directly from Bats drain, while the third site (III) irrigated with blending waters after the Bats mixing station. Data of the initial physical and chemical properties of the studied soils at the chosen three sites, which are presented in Table (1), show that the selected three soil sites have the same textural class as well as approximate similar physical and chemical properties.

The field experiment comprised 3 sites $x 16$ treatments $\mathrm{x} 4$ replicates $=192$ field plots, with an area of $3 \times 3.5 \mathrm{~m}^{2}$ for each one, separated by a polythene sheets to a depth of $1.0 \mathrm{~m}$ to avoid lateral salt and water movement. Each plot had a non-vegetated bund of 0.5 m. Table (2) shows chemical characteristics of the three irrigation water sources used in the chosen three soil sites. Also, data in Table (3) show analysis of the used gypsum (local gypsum enriched shale) and the organic manure (farmyard manure, FYM).

Sugar beet (Beta Vulgaris L.) was planted in $8 / 12 / 2005$. Plots were arranged in split split plot design with four replicates. Before planting phosphorous fertilizer was added at a level of $200 \mathrm{~kg}$ super phosphate $\left(15.5 \% \mathrm{P}_{2} \mathrm{O}_{5}\right) /$ fed. Nitrogen was added at a level $90 \mathrm{~kg}$ $\mathrm{N} /$ fed as ammonium nitrate $(33.5 \% \mathrm{~N})$ in three equal doses, i.e., after thinning, two and four weeks after thinning. The applied rates of gypsum were $0,2,4$ and 6 tons/fed, while that of organic manure was $0,15,30$ and $45 \mathrm{~m}^{3} / \mathrm{fed}$. The applied amounts of gypsum shale and organic manure were added at the designed rate in one dose before cultivation.

The applied irrigation system was normal flooding irrigation as practiced in the area. Harvesting of the sugar beet yield was after 180 days from planting $(9 / 6 / 2006)$ as its yield and total soluble solids in roots were recorded. After harvesting the sugar beet roots, soil sample were taken at a depth of $0-60 \mathrm{~cm}$ for laboratory analysis. Soil physical properties were determined according to Klute (1986) and soil chemical ones were determined according to Page et al. (1982). The obtained results of sugar beet response to the tested treatments were subjected to statistical analysis according to Snedecor and Cochran (1980).

Table 2. Chemical characteristics of the studied irrigation water sources

\begin{tabular}{lccc}
\hline \multicolumn{1}{c}{ Water characteristics } & Bahr Wahbey water & Bats drainage water & Blending water \\
\hline $\mathrm{pH}$ & 7.45 & 7.87 & 7.80 \\
EC $\left(\mathrm{dS} . \mathrm{m}^{-1}\right)$ & 0.95 & 3.90 & 1.76 \\
Soluble ions in m mole $L^{-1}:$ & & & 2.21 \\
$\mathrm{Ca}^{++}$ & 3.38 & 7.43 & 2.07 \\
$\mathrm{Mg}^{++}$ & 1.66 & 2.64 & 12.66 \\
$\mathrm{Na}^{+}$ & 5.25 & 28.42 & 0.66 \\
$\mathrm{~K}^{+}$ & 0.21 & 0.51 & 0.00 \\
$\mathrm{CO}_{3}^{--}$ & 0.00 & 0.00 & 3.27 \\
$\mathrm{HCO}_{3}^{-}$ & 2.15 & 2.78 & 9.75 \\
$\mathrm{Cl}^{-}$ & 4.51 & 23.20 & 4.83 \\
$\mathrm{SO}_{4}^{--}$ & 3.10 & 13.72 & 8.70 \\
$\mathrm{SAR}^{-}$ & 3.70 & 12.70 & \\
\hline
\end{tabular}

Table 3. Chemical characteristics of the used local gypsum and farmyard manure

\begin{tabular}{|c|c|}
\hline Properties & Value \\
\hline \multicolumn{2}{|c|}{ Local gypsum } \\
\hline pH (1:2.5 water suspension) & 7.10 \\
\hline EC in $1: 2.5$ water suspension $\left(\mathrm{dS} \mathrm{m}^{-1}\right)$ & 6.13 \\
\hline $\mathrm{CaCO}_{3} \%$ & 1.10 \\
\hline Gypsum \% & 75.62 \\
\hline \multicolumn{2}{|c|}{ Farmyard manure } \\
\hline $\mathrm{pH}(1: 2.5$ water suspension $)$ & 7.20 \\
\hline Organic matter $\%$ & 43.20 \\
\hline Organic carbon $\%$ & 25.12 \\
\hline Total nitrogen \% & 1.15 \\
\hline $\mathrm{C} / \mathrm{N}$ & 21.84 \\
\hline
\end{tabular}




\section{RESULTS AND DISCUSSIONS}

The effective role of the tested soil amendments, i.e., local gypsum enriched shale and farmyard manure, for minimizing the hazardous effects of the used low qualities of waters on both soil properties of the selected three sites, Tables (4 and 5), and the grown sugar beet root yield and quality could be discussed throughout the following items.

\section{Soil physical and chemical properties as affected} by the applied treatments:

\section{a. Soil physical properties:}

The short term uses of the irrigation waters varying in their qualities left their footprints on the tested soil properties after harvest of sugar beet, however, their changes depend mainly on both initial soil characteristics and the quality of the used irrigation water. Table (4) shows the obtained results of bulk density, hydraulic conductivity and available water after sugar beet harvest as affected by the tested treatments, which could be discussed as follows:

\section{Bulk density:}

Soil bulk density is closely related to the properties of solid phase and pore space, which their changes depending upon soil texture, water quality and other soil factors including soil salinity (Farrag, 2000). Accordingly, data presented in Table (5) reveal that soil bulk density value tended to increase slightly in the sites irrigated with Bats saline drainage and/or blending waters as compared to those irrigated with Bahr Wahbey waters. The increment in soil bulk density is probably due to its negatively affected by salinity levels of either irrigation water or irrigate soil as well as the specific ions that are dominated. That is true, since the influence of Na-salt accumulations was enhanced the dispersion of soil particles and create a renewed soil bulk volume that accompanied by fine pores. So that, applying organic manure and gypsum shale resulted in a significantly decreased in soil bulk density, which reached minimum values at the combined treatments of soil plots received $\left(30 \mathrm{~m}^{3} / \mathrm{fed}\right.$ organic manure +4 ton gypsum) and $\left(45 \mathrm{~m}^{3} / \mathrm{fed}\right.$ organic manure +6 ton gypsum), with insignificant differences between the two treatments. This is confirmed by the calculated improvement efficiency, which could be expressed as decrease by -9.70 and $-11.70 \%$ with site I ; -2.7 and $4.7 \%$ with site II and -6.8 and $-8.2 \%$ with site III less than the control, respectively.

\section{Hydraulic conductivity:}

Data presented in Table (4) show that values of hydraulic conductivity were decreased in the sites irrigated with low quality waters (Bats saline drainage water) as compared to those irrigated with Bahr Wahbey water. This refers to the degradation effect of $\mathrm{Na}$-salts on soil aggregation as well as lowering the values of hydraulic conductivity. In this connection, the additions of organic manure and gypsum especially with increasing the applied rates, showed a clearly improvement on soil permeability, with a significantly positive effect and improvement efficiency for hydraulic conductivity of -18.75 and $-28.75 \%$ with site I ; -15.83 and $-18.25 \%$ with site II and -26.5 and $30.0 \%$ with site III at the applied two treatments of (30 $\mathrm{m}^{3} /$ fed organic manure +4 ton gypsum) and $\left(45 \mathrm{~m}^{3} / \mathrm{fed}\right.$ organic manure +6 ton gypsum), respectively, as compared with the control treatments.

\section{Available water:}

The obtained results of Table (4) show that values of available water were decreased with increasing salinity levels of the used irrigation waters being in descending order as follows: Bahr Wahbey water > blending water at bats mixing station $>$ Bats drainage water. It well known that excess soluble salts in the root zone restrict plant roots from withdrawing water from surrounding soil and effectively reducing the plant available water (Bauder, 2001; Bauder and Brock, 2001 and USDA, Natural Resources Conservation Service, 2002). By applying organic manure and gypsum, it is seen that available water range was significantly increased and reached its greatest values at the combined treatments, which received $\left(30 \mathrm{~m}^{3} / \mathrm{fed}\right.$ organic manure +4 ton gypsum) and $\left(45 \mathrm{~m}^{3} / \mathrm{fed}\right.$ organic manure +6 ton gypsum), with insignificant differences between them. These findings are emphasized by the values of improvement efficiency that could be expressed as increases by +26.60 and $+29.50 \%$ with site I; +16.00 and $20.70 \%$ with site II and by +45.60 and $+50.20 \%$ with III higher than the control treatment for the aforementioned two treatments, respectively.

\section{b. Soil chemical properties:}

\section{Organic matter contents:}

The obtained data in Table (4) show that organic matter contents were reduced in soils irrigated with bats saline drainage water as compared with those irrigated with either Bahr Wahbey water or the blending water produced from the mixing station. The changes in organic matter contents of the experiment treatments were clearly due to additions of organic manure being at highest value of $0.32 \%$ with the treatment of soil received $45 \mathrm{~m}^{3} /$ fed organic manure +6 ton gypsum and irrigated with Bahr Wahbey water. Mostly, the changes were within slight range of increases. 
Table 4. Effect of treatments on the studied soil physical and chemical properties Treatments Physical properties

Chemical properties

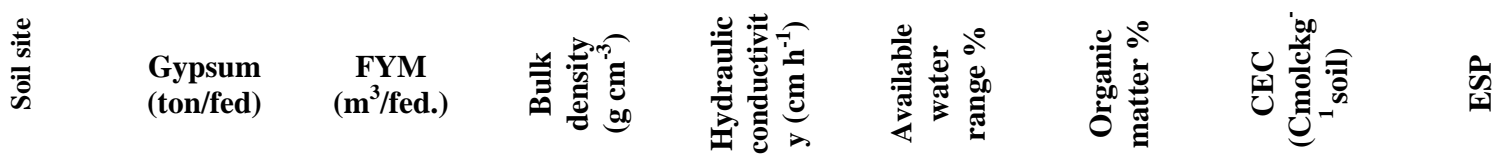

\begin{tabular}{|c|c|c|c|c|c|c|c|c|}
\hline \multirow{16}{*}{ 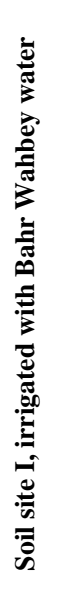 } & 0 & \multirow{4}{*}{0} & 1.45 & 11.20 & 6.95 & 0.12 & 8.40 & 6.91 \\
\hline & 2 & & 1.39 & 10.95 & 7.90 & 0.17 & 8.78 & 5.81 \\
\hline & 4 & & 1.37 & 10.70 & 8.00 & 0.19 & 9.35 & 5.45 \\
\hline & 6 & & 1.35 & 10.30 & 8.20 & 0.22 & 9.83 & 5.09 \\
\hline & \multirow{3}{*}{0} & 15 & 1.37 & 10.75 & 7.10 & 0.20 & 8.87 & 6.20 \\
\hline & & 30 & 1.35 & 10.20 & 7.40 & 0.24 & 9.45 & 5.82 \\
\hline & & 45 & 1.33 & 10.00 & 8.30 & 0.26 & 9.93 & 5.04 \\
\hline & 2 & \multirow{3}{*}{15} & 1.34 & 9.75 & 8.00 & 0.24 & 9.54 & 5.87 \\
\hline & 4 & & 1.33 & 9.50 & 8.60 & 0.26 & 10.16 & 5.31 \\
\hline & 6 & & 1.31 & 8.95 & 8.67 & 0.27 & 10.68 & 4.96 \\
\hline & 2 & \multirow{3}{*}{30} & 1.32 & 9.40 & 8.50 & 0.26 & 10.15 & 4.93 \\
\hline & 4 & & 1.31 & 9.10 & 8.80 & 0.29 & 10.81 & 4.63 \\
\hline & 6 & & 1.29 & 8.60 & 8.90 & 0.30 & 11.37 & 4.31 \\
\hline & 2 & \multirow{3}{*}{45} & 1.30 & 8.69 & 8.75 & 0.28 & 10.93 & 4.12 \\
\hline & 4 & & 1.29 & 8.50 & 9.00 & 0.30 & 11.50 & 4.09 \\
\hline & 6 & & 1.28 & 7.98 & 9.18 & 0.32 & 12.10 & 4.05 \\
\hline \multirow{16}{*}{ 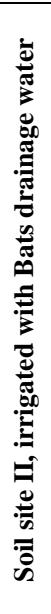 } & 0 & \multirow{4}{*}{0} & 1.48 & 12.00 & 6.00 & 0.13 & 7.83 & 14.94 \\
\hline & 2 & & 1.48 & 11.10 & 6.50 & 0.13 & 7.95 & 11.07 \\
\hline & 4 & & 1.46 & 10.85 & 6.60 & 0.15 & 8.00 & 10.50 \\
\hline & 6 & & 1.45 & 10.55 & 6.80 & 0.18 & 8.20 & 9.51 \\
\hline & \multirow{3}{*}{0} & 15 & 1.47 & 10.98 & 6.73 & 0.14 & 8.10 & 11.97 \\
\hline & & 30 & 1.45 & 10.55 & 6.85 & 0.17 & 8.30 & 11.20 \\
\hline & & 45 & 1.44 & 10.35 & 6.93 & 0.19 & 8.60 & 9.77 \\
\hline & 2 & \multirow{3}{*}{15} & 1.46 & 10.85 & 6.60 & 0.16 & 8.10 & 11.23 \\
\hline & 4 & & 1.45 & 10.75 & 6.90 & 0.17 & 8.19 & 10.13 \\
\hline & 6 & & 1.43 & 10.45 & 7.00 & 0.20 & 8.62 & 9.63 \\
\hline & 2 & \multirow{3}{*}{30} & 1.45 & 10.65 & 6.80 & 0.17 & 8.28 & 9.42 \\
\hline & 4 & & 1.44 & 10.10 & 6.96 & 0.19 & 8.71 & 8.73 \\
\hline & 6 & & 1.42 & 9.98 & 7.10 & 0.23 & 9.17 & 7.96 \\
\hline & 2 & \multirow{3}{*}{45} & 1.44 & 10.10 & 6.90 & 0.20 & 8.81 & 7.95 \\
\hline & 4 & & 1.42 & 9.95 & 7.10 & 0.22 & 9.27 & 7.44 \\
\hline & 6 & & 1.41 & 9.81 & 7.24 & 0.25 & 9.76 & 7.17 \\
\hline \multirow{16}{*}{ 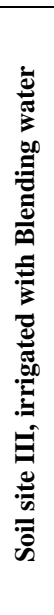 } & 0 & \multirow{4}{*}{0} & 1.46 & 11.90 & 5.70 & 0.14 & 7.58 & 9.76 \\
\hline & 2 & & 1.45 & 10.20 & 6.30 & 0.16 & 7.78 & 8.10 \\
\hline & 4 & & 1.42 & 9.98 & 6.75 & 0.18 & 7.86 & 7.62 \\
\hline & 6 & & 1.41 & 9.30 & 7.89 & 0.20 & 7.98 & 7.39 \\
\hline & \multirow{3}{*}{0} & 15 & 1.43 & 10.70 & 6.95 & 0.19 & 7.90 & 8.73 \\
\hline & & 30 & 1.40 & 9.55 & 6.85 & 0.20 & 7.95 & 8.30 \\
\hline & & 45 & 1.39 & 9.00 & 7.92 & 0.22 & 8.30 & 7.59 \\
\hline & 2 & \multirow{3}{*}{15} & 1.39 & 9.75 & 7.95 & 0.19 & 9.98 & 8.12 \\
\hline & 4 & & 1.37 & 9.45 & 8.10 & 0.21 & 10.40 & 7.60 \\
\hline & 6 & & 1.36 & 8.90 & 8.30 & 0.23 & 10.74 & 7.26 \\
\hline & 2 & \multirow{3}{*}{30} & 1.37 & 9.10 & 8.00 & 0.22 & 10.51 & 7.99 \\
\hline & 4 & & 1.36 & 8.75 & 8.30 & 0.24 & 10.95 & 7.31 \\
\hline & 6 & & 1.35 & 8.66 & 8.50 & 0.27 & 11.30 & 6.90 \\
\hline & 2 & \multirow{3}{*}{45} & 1.36 & 8.90 & 8.20 & 0.24 & 10.95 & 7.03 \\
\hline & 4 & & 1.35 & 8.75 & 8.45 & 0.27 & 11.41 & 6.40 \\
\hline & 6 & & 1.34 & 8.33 & 8.56 & 0.30 & 11.89 & 5.90 \\
\hline
\end{tabular}


Table 5. Effect of treatments on ECe and soluble ions in soil paste extracts of the studied soils

\begin{tabular}{|c|c|c|c|c|c|c|c|c|c|c|c|c|}
\hline \multirow{2}{*}{ 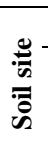 } & \multicolumn{2}{|c|}{ Treatments } & \multirow{2}{*}{$\begin{array}{l}\text { Soil } \\
\text { pH } \\
\text { (soil } \\
\text { paste) }\end{array}$} & \multirow[b]{2}{*}{ 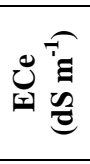 } & \multicolumn{4}{|c|}{ Soluble cations $\left(\mathrm{mmole}^{-1}\right)$} & \multicolumn{4}{|c|}{ Soluble anions $\left(\mathrm{mmole}^{-1}\right)$} \\
\hline & $\begin{array}{l}\text { Gypsum } \\
\text { (ton/fed) }\end{array}$ & $\begin{array}{c}\text { FYM } \\
\left(\mathbf{m}^{3} / \text { fed. }\right)\end{array}$ & & & $\mathbf{C a}^{++}$ & $\mathbf{M g}^{++}$ & $\mathbf{N a}^{+}$ & $\mathbf{K}^{+}$ & $\mathrm{CO}_{3}{ }^{--}$ & $\mathrm{HCO}_{3}^{--}$ & $\mathrm{Cl}^{-}$ & $\mathrm{SO}_{4}^{-}$ \\
\hline \multirow{16}{*}{ 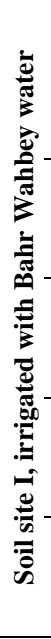 } & 0 & \multirow{4}{*}{0} & 7.92 & 3.77 & 11.11 & 9.07 & 17.15 & 0.17 & 0.00 & 1.86 & 31.67 & 3.98 \\
\hline & 2 & & 7.91 & 3.59 & 10.74 & 8.78 & 16.12 & 0.17 & 0.00 & 1.77 & 29.99 & 4.24 \\
\hline & 4 & & 7.90 & 3.47 & 10.39 & 8.49 & 15.60 & 0.17 & 0.00 & 1.70 & 28.87 & 4.28 \\
\hline & 6 & & 7.90 & 3.38 & 10.11 & 8.26 & 15.17 & 0.16 & 0.00 & 1.65 & 28.02 & 4.30 \\
\hline & \multirow{3}{*}{0} & 15 & 7.90 & 3.43 & 10.26 & 8.39 & 15.40 & 0.16 & 0.00 & 1.69 & 28.74 & 3.79 \\
\hline & & 30 & 7.88 & 3.34 & 9.99 & 8.16 & 14.99 & 0.16 & 0.00 & 1.65 & 27.99 & 3.73 \\
\hline & & 45 & 7.86 & 3.21 & 9.30 & 8.70 & 13.94 & 0.14 & 0.00 & 1.58 & 26.97 & 3.60 \\
\hline & 2 & \multirow{3}{*}{15} & 7.88 & 3.36 & 10.05 & 8.21 & 15.08 & 0.16 & 0.00 & 1.83 & 27.90 & 4.27 \\
\hline & 4 & & 7.87 & 3.22 & 9.62 & 7.86 & 14.45 & 0.15 & 0.00 & 1.58 & 26.73 & 4.32 \\
\hline & 6 & & 7.87 & 3.16 & 9.45 & 7.72 & 14.18 & 0.15 & 0.00 & 1.54 & 26.19 & 4.35 \\
\hline & 2 & \multirow{3}{*}{30} & 7.86 & 3.25 & 9.73 & 7.96 & 14.61 & 0.15 & 0.00 & 1.58 & 26.83 & 4.28 \\
\hline & 4 & & 7.85 & 3.12 & 9.33 & 7.62 & 14.00 & 0.15 & 0.00 & 1.53 & 25.92 & 4.35 \\
\hline & 6 & & 7.82 & 2.98 & 8.92 & 7.29 & 13.39 & 0.15 & 0.00 & 1.46 & 24.73 & 4.37 \\
\hline & 2 & \multirow{3}{*}{45} & 7.80 & 3.17 & 9.48 & 7.75 & 14.22 & 0.15 & 0.00 & 1.56 & 26.48 & 4.29 \\
\hline & 4 & & 7.78 & 3.04 & 9.10 & 7.44 & 13.66 & 0.14 & 0.00 & 1.49 & 25.29 & 4.38 \\
\hline & 6 & & 7.75 & 2.90 & 8.71 & 7.11 & 13.06 & 0.14 & 0.00 & 1.42 & 24.12 & 4.40 \\
\hline \multirow{16}{*}{ 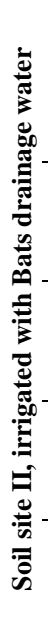 } & 0 & \multirow{4}{*}{0} & 8.13 & 6.38 & 19.15 & 15.64 & 28.70 & 0.30 & 0.00 & 3.15 & 53.64 & 7.09 \\
\hline & 2 & & 8.08 & 5.79 & 17.37 & 14.19 & 26.06 & 0.28 & 0.00 & 2.85 & 48.31 & 6.81 \\
\hline & 4 & & 8.06 & 5.62 & 16.87 & 13.77 & 25.31 & 0.27 & 0.00 & 2.75 & 46.86 & 6.90 \\
\hline & 6 & & 8.05 & 5.50 & 16.50 & 13.48 & 24.76 & 0.26 & 0.00 & 2.69 & 45.75 & 7.02 \\
\hline & \multirow{3}{*}{0} & 15 & 8.12 & 5.21 & 15.64 & 12.77 & 23.46 & 0.25 & 0.00 & 2.57 & 43.81 & 5.76 \\
\hline & & 30 & 8.10 & 5.10 & 15.31 & 12.51 & 22.97 & 0.24 & 0.00 & 2.52 & 42.89 & 5.79 \\
\hline & & 45 & 8.09 & 5.06 & 15.18 & 12.41 & 22.78 & 0.24 & 0.00 & 2.50 & 42.54 & 5.82 \\
\hline & 2 & \multirow{3}{*}{15} & 8.03 & 5.15 & 15.46 & 12.63 & 23.19 & 0.25 & 0.00 & 2.54 & 43.00 & 6.90 \\
\hline & 4 & & 8.02 & 5.04 & 15.12 & 12.35 & 22.69 & 0.24 & 0.00 & 2.37 & 42.00 & 6.98 \\
\hline & 6 & & 8.00 & 4.97 & 14.92 & 12.19 & 22.39 & 0.24 & 0.00 & 2.43 & 41.00 & 7.06 \\
\hline & 2 & \multirow{3}{*}{30} & 7.98 & 5.10 & 15.31 & 12.50 & 22.97 & 0.24 & 0.00 & 2.42 & 42.74 & 7.00 \\
\hline & 4 & & 7.97 & 4.96 & 14.88 & 12.16 & 22.33 & 0.24 & 0.00 & 2.43 & 41.34 & 7.10 \\
\hline & 6 & & 7.95 & 4.90 & 14.71 & 12.02 & 22.07 & 0.24 & 0.00 & 2.40 & 40.77 & 7.19 \\
\hline & 2 & \multirow{3}{*}{45} & 7.91 & 5.01 & 15.03 & 12.28 & 22.56 & 0.24 & 0.00 & 2.46 & 41.90 & 7.10 \\
\hline & 4 & & 7.89 & 4.92 & 14.55 & 12.63 & 21.83 & 0.23 & 0.00 & 2.41 & 41.03 & 7.21 \\
\hline & 6 & & 7.85 & 4.32 & 12.97 & 10.59 & 19.46 & 0.21 & 0.00 & 2.11 & 35.85 & 7.25 \\
\hline & 0 & & 8.04 & 5.10 & 15.41 & 12.58 & 23.11 & 0.24 & 0.00 & 2.53 & 41.95 & 6.95 \\
\hline & 2 & 0 & 7.95 & 4.86 & 14.58 & 11.92 & 21.89 & 0.23 & 0.00 & 2.30 & 40.70 & 6.79 \\
\hline ث્ّ & 4 & 0 & 7.94 & 4.75 & 14.26 & 11.65 & 21.39 & 0.23 & 0.00 & 2.30 & 39.50 & 6.85 \\
\hline 3 & 6 & & 7.94 & 4.64 & 13.93 & 11.38 & 20.90 & 0.22 & 0.00 & 2.27 & 38.60 & 7.00 \\
\hline : & & 15 & 7.95 & 4.73 & 14.20 & 11.59 & 21.29 & 0.23 & 0.00 & 2.34 & 39.77 & 5.70 \\
\hline है & 0 & 30 & 7.94 & 4.59 & 13.78 & 11.25 & 20.68 & 0.22 & 0.00 & 2.27 & 38.68 & 5.76 \\
\hline$=$ & & 45 & 7.93 & 4.48 & 13.44 & 10.98 & 20.17 & 0.22 & 0.00 & 2.21 & 37.67 & 5.80 \\
\hline 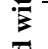 & 2 & & 7.93 & 4.60 & 13.80 & 11.28 & 20.71 & 0.22 & 0.00 & 2.26 & 38.50 & 6.85 \\
\hline$=$ & 4 & 15 & 7.92 & 4.51 & 13.53 & 11.06 & 20.30 & 0.22 & 0.00 & 2.20 & 37.50 & 6.96 \\
\hline . & 6 & & 7.90 & 4.43 & 13.29 & 10.86 & 19.95 & 0.22 & 0.00 & 2.10 & 36.80 & 7.04 \\
\hline. & 2 & & 7.89 & 4.57 & 13.72 & 11.20 & 20.58 & 0.22 & 0.00 & 2.21 & 38.30 & 6.97 \\
\hline 目 & 4 & 30 & 7.87 & 4.46 & 13.38 & 10.93 & 20.08 & 0.22 & 0.00 & 2.19 & 37.10 & 7.08 \\
\hline : & 6 & & 7.86 & 4.39 & 13.18 & 10.76 & 19.77 & 0.22 & 0.00 & 2.10 & 36.40 & 7.15 \\
\hline$\overline{8}$ & 2 & & 7.84 & 4.50 & 13.50 & 11.03 & 20.26 & 0.21 & 0.00 & 2.20 & 37.61 & 7.09 \\
\hline & 4 & 45 & 7.82 & 4.41 & 13.27 & 10.80 & 19.85 & 0.20 & 0.00 & 2.16 & 36.70 & 7.20 \\
\hline & 6 & & 7.80 & 4.32 & 12.97 & 10.59 & 19.45 & 0.20 & 0.00 & 2.10 & 35.90 & 7.22 \\
\hline
\end{tabular}




\section{Cation exchange capacity (CEC) and exchangeable sodium percent (ESP):}

Comparing the values of CEC and ESP soils irrigated with the Bahr Wahbey water and Bats drainage water and blending water, data in Table (4) declared a progressively increase in the ESP values in soil received directly Bats saline drainage water on account of the exchangeable other cations. Also, Table (4) pointed out that the noticeable decreases in ESP values were more related with the additions of organic manure, gypsum shale and/or mixture of them.

The greatest decrease was more associated with soils received treatment of $\left(30 \mathrm{~m}^{3} / \mathrm{fed}\right.$. organic manure + 4 ton/fed gypsum) or $\left(45 \mathrm{~m}^{3} / \mathrm{fed}\right.$ organic manure +6 ton/fed gypsum) with insignificant differences and irrigated with Bahr Wahbey water. It was also obvious from the data presented in Table (4) that the ESP values tend to be relatively high in the soil irrigated with blending water.

This behavior is confirmed by relatively high values of soluble sodium and SAR in the used low quality waters, especially the Bats saline drainage one. The obtained results elucidate also those additions of organic manure, gypsum and/or mixture of them to the tested three soil sites, which prove an amelioration effect in both CEC and ESP values, mainly due to the released organic colloids and soluble calcium against soluble sodium.

\section{Soil pH:}

Soil $\mathrm{pH}$ may be one of the most important parameters, which pinpoint the over all changes in soil chemical properties. Data presented in Table (5) indicate that soil $\mathrm{pH}$ values tended to increase with insignificantly affected as salinity levels of irrigation water increased.

On the other hand, the additions of either gypsum shale and/or organic manure resulted in a slightly decrease in soil $\mathrm{pH}$, being a maximum decease with increasing thee applied rates up to the combined treatments which received $\left(30 \mathrm{~m}^{3} / \mathrm{fed}\right.$ organic manure + 4 ton/fed gypsum) and $\left(45 \mathrm{~m}^{3} / \mathrm{fed}\right.$ organic manure +6 ton/fed gypsum), as the changes in soil $\mathrm{pH}$ was from 8.13 to 7.97 and 7.85 , respectively, with both treatments which receive Bats saline drainage water for irrigation. This may be due to that $\mathrm{H}^{+}$ions are released from the exchange complex by the influence of the dominant soluble cations in the applied saline waters or due to increasing solubility of the added $\mathrm{CaSO}_{4}$ and the consequence sulfate transformation, which led to decrease in the soil pH values (Mostafa et al., 2004).
Due to the diversity of used irrigation waters, it is necessary to set up particular criteria for evaluating the quality of irrigation water. In this respect, the most important characteristics that may be considered here in determining water quality are salinity and sodicity status [expressed as electrical conductivity values (ECe) and sodium adsorption ratio (SAR)]. Based on the criteria of irrigation water salinity levels after FAO (1985), the used irrigation waters could be classified as irrigation waters of EC ranged from 0.7 to $3.0 \mathrm{dS} / \mathrm{m}$ (i.e., Bahr Wahbey and blending waters), which are considered slight to moderate salinity hazardous, while that of salinity above $3.0 \mathrm{dS} / \mathrm{m}$ (i.e., Bats saline drainage water) is considered of high to very high salinity hazardous (El-Shakweer and Abdel-Hafeez, 2008). The obtained data of Table (5) show that highest ECe values were found in the untreated soils irrigated with Bats saline drainage water (without additions of soil amendments), while the lowest ones were associated with those irrigated by Bahr Wahbey water. The data elucidated that additions of organic manure and gypsum shale, especially in case of combined treatments (i.e., 30 $\mathrm{m}^{3} /$ fed organic manure +4 ton/fed gypsum shale or 45 $\mathrm{m}^{3} /$ fed organic manure +6 ton/fed gypsum shale) tended to decrease ECe values of the tested soils of the three sites, which prove ameliorating effects due to the effective role of applied such soil amendments.

Concerning the redistribution pattern of soluble ions, the data presented in Table (5) points out that the major cations and anions of the saturated extract of the tested soils showed gradually increases with increasing the salt levels of irrigation water. This is due to alternating irrigation saline water replacement of soil solution; and thus results in different ionic concentrations in soil solution. It is also noticed that the redistribution pattern of soluble cations possesses a descending trend of $\mathrm{Na}^{+}>\mathrm{Ca}^{++}>\mathrm{Mg}^{++}>\mathrm{K}^{+}$in soils irrigated with Bahr Wahbey water, Bats drainage water and blended water. The soluble anions of paste extract trends were similar for all the tested treatments and takes a descending pattern of $\mathrm{Cl}^{-}>\mathrm{SO}_{4}{ }^{\circ}$, $\mathrm{HCO}_{-}$.

\section{Root yield and quality of sugar beet as affected by the applied treatments:}

\section{a. Roots yield:}

Data presented in Table (6) show that root yield and quality of sugar beet crop were significantly affected by the tested irrigation water qualities and the used soil amendments. Significant decreases of root yield and its quality were observed in soil plots irrigated with Bats

\section{Soil electrical conductivity (ECe) and soluble ions:}


Table 6. Effect of treatments on root yield of sugar beet at harvest and its content of total soluble solids \%

\begin{tabular}{|c|c|c|c|c|c|c|}
\hline \multirow[b]{2}{*}{ 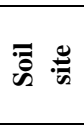 } & \multicolumn{2}{|c|}{ Treatments } & \multicolumn{2}{|c|}{ Sugar beet parameters } & \multicolumn{2}{|c|}{ Statistical analysis } \\
\hline & $\begin{array}{l}\text { Gypsum } \\
\text { (ton/fed.) }\end{array}$ & $\begin{array}{c}\text { FYM } \\
\left(\mathbf{m}^{3} / \text { fed. }\right)\end{array}$ & $\begin{array}{c}\text { Root yield } \\
\text { (kg/plot) }\end{array}$ & $\begin{array}{c}\text { Total soluble } \\
\text { solids \% }\end{array}$ & Treatment & L.S.D. at 0.05 \\
\hline \multirow{16}{*}{ 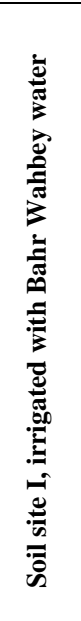 } & 0 & \multirow{4}{*}{0} & 43.680 & 20.970 & \multirow{3}{*}{\multicolumn{2}{|c|}{ Root yield (kg/plot) }} \\
\hline & 2 & & 48.045 & 21.34 & & \\
\hline & 4 & & 50.499 & 21.53 & & \\
\hline & 6 & & 50.687 & 21.66 & \multirow{2}{*}{ Water quality (1) } & \multirow{2}{*}{0.0499} \\
\hline & \multirow{3}{*}{0} & 15 & 50.221 & 21.17 & & \\
\hline & & 30 & 54.597 & 21.38 & \multirow{2}{*}{ Organic manure (2) } & \multirow{2}{*}{0.0289} \\
\hline & & 45 & 54.80 & 21.46 & & \\
\hline & 2 & \multirow{3}{*}{15} & 56.775 & 21.187 & \multirow{2}{*}{ Gypsum (3) } & \multirow{2}{*}{0.0256} \\
\hline & 4 & & 59.400 & 21.403 & & \\
\hline & 6 & & 59.623 & 21.483 & \multirow{2}{*}{$1 \times 2$} & \multirow{2}{*}{0.0516} \\
\hline & 2 & \multirow{3}{*}{30} & 61.709 & 21.593 & & \\
\hline & 4 & & 62.872 & 21.623 & \multirow{2}{*}{$1 \times 3$} & \multirow{2}{*}{0.0444} \\
\hline & 6 & & 62.952 & 21.667 & & \\
\hline & 2 & \multirow{3}{*}{45} & 61.544 & 21.517 & & \\
\hline & 4 & & 63.009 & 21.523 & $2 \times 3$ & 0.0512 \\
\hline & 6 & & 63.148 & 21.564 & & \\
\hline & 0 & & 25.770 & 23.710 & $1 \times 2 \times 3$ & 0.0889 \\
\hline $\bar{\Xi}$ & 2 & & 29.635 & 23.76 & & \\
\hline $\bar{z}$ & 4 & 0 & 30.408 & 23.82 & & \\
\hline$\underset{\Xi}{\mathscr{E}}$ & 6 & & 30.540 & 23.92 & & \\
\hline 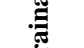 & & 15 & 30.924 & 23.66 & & \\
\hline 5 & 0 & 30 & 32.212 & 23.72 & & \\
\hline$\overbrace{\tilde{N}}^{n}$ & & 45 & 32.438 & 23.77 & & \\
\hline$=$ & 2 & & 32.470 & 23.410 & & \\
\hline 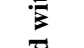 & 4 & 15 & 36.305 & 23.470 & & \\
\hline 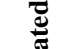 & 6 & & 36.592 & 23.510 & Total sol & ds $\%$ \\
\hline 营 & 2 & & 35.809 & 23.210 & & \\
\hline$\cong$ & 4 & 30 & 37.576 & 23.317 & & \\
\hline 0 & 6 & & 37.623 & 23.390 & Water quality (1) & 0.0556 \\
\hline : & 2 & & 35.978 & 23.223 & Oroanic manure (2) & 00562 \\
\hline & 4 & 45 & 37.666 & 23.335 & Organic manure (2) & 0.0562 \\
\hline & 6 & & 37.746 & 23.363 & Gyncum (3) & 00458 \\
\hline & 0 & & 31.210 & 22.810 & Gypsum (3) & 0.0458 \\
\hline & 2 & & 38.050 & 23.43 & & \\
\hline है & 4 & 0 & 39.178 & 23.86 & $1 \times 2$ & 0.0973 \\
\hline 3 & 6 & & 39.415 & 23.93 & & \\
\hline 现 & & 15 & 39.014 & 23.69 & $1 \times 3$ & 0.0793 \\
\hline$\frac{\Xi}{0}$ & 0 & 30 & 40.574 & 23.78 & & \\
\hline$=$ & & 45 & 40.772 & 23.86 & $2 \times 3$ & 0.0916 \\
\hline$\vec{z}$ & 2 & & 40.885 & 21.167 & & \\
\hline 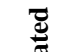 & 4 & 15 & 41.198 & 21.393 & $1 \times 2 \times 3$ & 0.1586 \\
\hline . & 6 & & 41.319 & 21.513 & & \\
\hline$\Xi$ & 2 & & 48.258 & 20.813 & & \\
\hline 国 & 4 & 30 & 49.259 & 20.967 & & \\
\hline 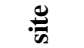 & 6 & & 49.504 & 21.067 & & \\
\hline$\overline{8}$ & 2 & & 48.377 & 20.797 & & \\
\hline & 4 & 45 & 49.555 & 20.517 & & \\
\hline & 6 & & 49.662 & 20.718 & & \\
\hline
\end{tabular}


saline drainage water and blending waters as compared with those receive Bahr Wahbey water. The depressive effect of salinity on root yield is probably due to the effect of osmotic inhibition on water absorption as well as accumulation of certain ions in high concentrations in plant tissues caused an alteration for the mineral and nutritional balance of sugar beet plants.

Also, the data of Table (6) show that the greatest sugar beet roots yields were obtained with the combined treatments of $\left(30 \mathrm{~m}^{3} / \mathrm{fed}\right.$. organic manure +4 ton/fed gypsum) and $\left(45 \mathrm{~m}^{3} / \mathrm{fed}\right.$ organic manure +6 ton/fed gypsum), with insignificant differences between the two treatments.

\section{b. Total soluble solids (TSS) in sugar beet roots:}

The obtained data of Table (6) indicate that the TSS in sugar beet roots showed a significant increase with increasing the salinity levels of the used irrigation water. The noticeable increase in TSS under high salinity is mainly due to high concentration of solutes which negatively affect juice purity This finding is supported by the results obtained by Higazy et al. (1995), Darwhish et al. (1995) and Kandil et al. (1999) who reported that the increase in soil salinity produced juice of high ash (impurities) and hence, leads to a reducing in quality. The depressive effect of salinity on total soluble solids of root yield of sugar beet is mainly due to alteration of mineral balance of the plant (Khafagi and El-Lawandy, 1996) and/or due to the reduction in photosynthetic activity and carbohydrates metabolism (Heur and Plaut, 1989).

III. Improvement efficiencies of the used soil amendments for minimizing the harmful effects of the tested low qualities of irrigation water:

Long-term irrigation with low quality waters influenced the built up of salts and ESP in the soil, as the increase in SAR and salinity in irrigation water increased $\mathrm{pH}, \mathrm{EC}$ and ESP in soil. Under the tested field experiment conditions and the tested three qualities of irrigation water, application of organic manure and gypsum at the tested rates proved different levels of improvements efficiencies (as percentages above or less than the control) in both physical and chemical properties of the studied soils as well as sugar beet root yield and its quality.

\section{a. Improvement efficiencies in soil properties:}

As seen in the obtained results of Table (7), the best values of improvement efficiency in the studied soil physical properties, i.e., bulk density, hydraulic conductivity, available water, organic matter content, $\mathrm{pH}, \mathrm{ECe}, \mathrm{CEC}$ and ESP were found with the treatments of $\left(30 \mathrm{~m}^{3} / \mathrm{fed}\right.$ organic manure +4 ton/fed gypsum $)$ and $\left(45 \mathrm{~m}^{3} /\right.$ fed organic manure +6 ton/fed gypsum), with insignificant differences between the two treatments, followed by the other combined and solely ones under study. It is noteworthy to mention that calculations of improvement efficiencies gained the best values in case of irrigation with Bahr Wahbey water, followed by blending water and Bats drainage water.

\section{b. Improvement efficiencies in sugar beet root yield and total soluble solids:}

Applications of organic manure and gypsum showed an increase in sugar beet root yield vs. a decrease in total soluble solids. The best improvement in sugar beet root yield and decrease in total soluble solids were found with the treatments of $\left(30 \mathrm{~m}^{3} / \mathrm{fed}\right.$ organic manure +4 ton/fed gypsum shale) and (45 $\mathrm{m}^{3} /$ fed organic manure +6 ton/fed gypsum), which gained the greatest values of improvement efficiency with insignificant differences between the two treatments, followed by the other combined and solely ones under study, as shown in Table (7). Also, it is evident that the obtained values of improvement efficiency for both sugar beet root yield and total soluble solids gained the best values in case of soil receive irrigation water from Bahr Wahbey water, followed by blending water and Bats drainage water.

Therefore, it could be concluded that the soils continuously irrigated with low quality irrigation waters for a long-term use are suffering from substantial deterioration of soil properties, which result in significant decline in crop yield and its quality. The harmful effects were more pronounced due to higher built up of salts and ESP, especially under Bats drainage water reuse. To sustain such soils from substantial deterioration of their properties, it should be recommended by application of organic manure integrated with gypsum, which was more beneficial than each alone.

The positive effect of the applied treatments leads to bring down the soil salinity and sodicity to achieve sustainable soil characteristics, and positively reflected on the grown plants. The conclusions drawn in this study may be applicable in other types of soil and environmental conditions, taking into consideration that the magnitude of deterioration in soil properties upon irrigation with low qualities waters and their amelioration with either inorganic or organic amendments that affect root yield and quality of sugar beet crop may vary and optimized under field conditions. 

Table 7. Improvement efficiency of the used soil amendments for the studied soil and sugar beet characteristics at the best two combined treatments

\begin{tabular}{|c|c|c|c|}
\hline \multirow{2}{*}{$\begin{array}{l}\stackrel{0}{\tilde{n}} \\
\stackrel{0}{\circ} \\
\mathscr{n}\end{array}$} & \multirow{2}{*}{$\begin{array}{l}\text { Soil and sugar beet } \\
\text { characteristics }\end{array}$} & \multicolumn{2}{|c|}{$\begin{array}{l}\text { Improvement efficiency values \% } \\
\text { of the best two combined treatments }\end{array}$} \\
\hline & & $\begin{array}{c}30 \mathrm{~m}^{3} / \text { fed. organic manure }+ \\
4 \text { ton gypsum }\end{array}$ & $\begin{array}{c}45 \mathrm{~m}^{3} / \text { fed. organic manure }+ \\
6 \text { ton gypsum }\end{array}$ \\
\hline \multirow{12}{*}{ 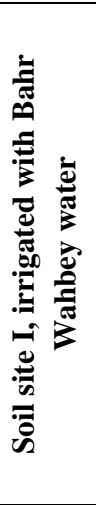 } & & Soil & \\
\hline & Bulk density & -9.70 & -11.70 \\
\hline & Hydraulic conductivity & -18.75 & -28.75 \\
\hline & Available water & +26.6 & +29.50 \\
\hline & Organic matter & +141.70 & +166.7 \\
\hline & $\mathrm{pH}$ & -0.90 & -2.15 \\
\hline & ECe & -.17 .24 & -23.10 \\
\hline & CEC & +28.70 & +44.05 \\
\hline & ESP & -33.00 & -41.40 \\
\hline & & Sugar beet & \\
\hline & Root yield & +43.90 & +44.60 \\
\hline & Total soluble solids & +3.10 & +2.80 \\
\hline \multirow{12}{*}{ 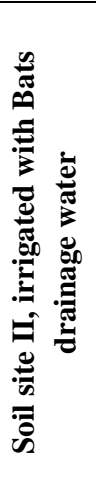 } & & Soil & \\
\hline & Bulk density & -2.70 & -4.70 \\
\hline & Hydraulic conductivity & -15.83 & -18.25 \\
\hline & Available water & +16.00 & +20.70 \\
\hline & Organic matter & +46.2 & +92.30 \\
\hline & $\mathrm{pH}$ & -1.97 & -3.40 \\
\hline & $\mathrm{ECe}$ & -22.30 & -32.30 \\
\hline & CEC & +11.20 & +24.60 \\
\hline & ESP & -42.20 & -52.00 \\
\hline & & Sugar beet & \\
\hline & Root yield & +45.80 & +46.50 \\
\hline & Total soluble solids & -0.4 & -2.00 \\
\hline \multirow{12}{*}{ 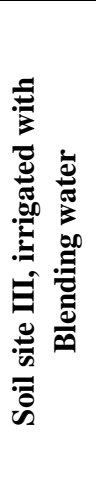 } & & Soil & \\
\hline & Bulk density & -6.80 & -8.20 \\
\hline & Hydraulic conductivity & -26.50 & -30.00 \\
\hline & Available water & +45.60 & +50.20 \\
\hline & Organic matter & +71.40 & +114.30 \\
\hline & $\mathrm{pH}$ & -2.11 & -.2 .99 \\
\hline & ECe & -12.50 & -.15 .30 \\
\hline & CEC & +44.5 & +56.90 \\
\hline & ESP & -.25 .10 & -39.50 \\
\hline & & Sugar beet & \\
\hline & Root yield & +21.10 & +21.50 \\
\hline & Total soluble solids & -0.90 & -2.12 \\
\hline
\end{tabular}

\section{REFERENCES}

Abdel-Hafeez, A. A. A. (2008). Improving the hydro-physical potential of new reclaimed soil using environmentfriend local amendments at El-Fayoum Governorate, Egypt. Alex. J. Agric. Res. 53(2): 97-117.

Abdel-Razik, M.A. (2005). Studies on soil and water management practices of sugar beet plants under Fayoum conditions. Ph. D. Thesis, Fac. of Agric., Fayoum Univ., Egypt.
Ayers, O.R.S. and D.W. Westcot (1985). Water Quality for Agriculture. FAO Irrigation and drainage Paper No. 29, FAO, Rome.

Bauder, J. W. (2001). Interpretation of chemical analysis of irrigation water and water considered for land spreading "Personal communication". Montana State Univ., Bozeman, Montana.

Bauder, J. W. and T. I. Brock (2001). Irrigation water quality, soil amendments and crop effects on sodium leaching. Arid Land Research and Management, 15: 101-113. 
Celik I. A.; I. M. Ortaz and S.S. Kilic (2004). Effects of compost, mycorrhiza, manure and fertilizer on some physical properties of a Chromoxerert soil. Soil \& Till. Res., 78: 59-67.

Darwhish, Y. L.; H. A., Attar; F. A., Askar and M., El-Harris (1995). Sugar beet response to soil salinity and sodicity at northern, Nile Delta. Egypt. J. Soil Sci., 35(4): 395400.

El-Banna, M. M.; S. A., Gaafer; M. H., Selim and B. Sh., Zikri (1982). Studies on drainage water of Behira Governorate. Suitability of drainage water of Edko group drains for irrigation purposes. Agric. Res. Rev., 60(4): 285-315.

El-Shakweer, M.H.A. and A.A.A. Abdel-Hafeez (2008). Evaluation of salinity and sodicity hazards due to drainage water reuse for irrigation purposes in ElFayoum Governorate, Egypt. Alex. J. Agric. Res., 53(2): 119-128.

Ertli, T. T.; A. U., Marton and R. A., Foldeny (2004). Effect of $\mathrm{pH}$ and the role of organic matter in the adsorption of isoproturon on soils. Chemosphere 57: 771-779.

Farrag, F. R. M. (2000). Potential effects of low quality water for soil irrigation in El-Fayoum Governorate, Egypt. M.Sc. Thesis, El-Fayoum Fac. of Agric., Cairo Univ., Egypt.

Hanson, B.; S.R. Gartton and A.Fulton (1999). "Agriculture Salinity and Drainage". University of California Irrigation Program. University of California, Davis, USA.

Hegazi, I. M. A. (1999). Factors affecting utilization and development in lands and water resources of the northern area of El-Fayoum, Egypt. Ph. D. Thesis, ElFayoum Fac. Agric., Cairo Univ., Egypt.

Heuer, B. and Z. Plaut (1989). Photosynthesis and osmotic adjustment of two sugar beet cultivars grown under saline conditions. J. Exper. Bot. , 40 (213): 437-440.

Higazy, M. A.; M. M., Shehata and A. Allam, (1995). Free praline relation to salinity tolerance of three sugar beet varieties. Egypt. J. Agric. Res., 73(1): 175-191.

Grattan, S. R. (2002). Irrigation Water Salinity and Crop production. University of California, Division of agriculture and Natural Resources, Publication No. 8066.
Kandil, S. A.; M. S.A. Abo-El-Kheir and H.A. El-Zeiny (1999). Increasing salt tolerance of sugar beet (Beta Vulgaris, L.) plants through application of uniconazole. J. Agric. Sci. Monsoura Univ., 24 (7): 3413- 3425.

Khafagi, O. M. and W. I. El-Lawandy (1996). Salt tolerance of sugar beet (Beta Vulgaris, L.). II. Metabolic products and ion accumulation. Annals of Agric. Sci. Moshtohor products, 34 (4): 1647-1663.

Klute, A. Ed. (1986). Methods of Soil Analysis. Part 1: Physical and Mineralogical Methods ( $2^{\text {nd }}$ ed.). American Society of Agronomy, Madison, Wisconsin, USA.

Ministry of irrigation (1997). Report, Reuse of Drainage Water for Irrigation. Drainage Research Institute, Cairo, A.R.E.

Mostafa, M. A.; M. O. El-Sharawy and F. M., El-Boraei (2004). Use of seawater for wheat irrigation. II. Effect on soil chemical properties, Actual evapo-transpiration and water use efficiency. Inter. Conf. on Water Resources \& Arid Environment.

National Water Resources Plan for Egypt, NWRP (1999). Inception Report, The National Water Research Center (NWRC).

Page, A. I.; R. H. Miller and D. R. Keeney, (eds.) (1982). Methods of Soil Analysis. Part 2: Chemical and Microbiological Properties. The $2^{\text {nd }}$ Ed. American Society of Agronomy, Madison, Wisconsin, USA.

Shehata, A. A.; D.D. El-Badry and M. Hamdy (1983). Evaluating drainage water quality in some Egyptian Governorate. Egypt. J. Soil Sci., 23: 212-224.

Snedecor, G.W. and W.G. Cochran (1980). Statistical Methods. $7^{\text {th }}$ Ed. Iowa State University Press, USA

Van-Zov, H.C.J. and K.W. Jeans, Eds. (1992). Environmental Profile, Fayoum Governorate, Egypt. Background study, Report document prepared by the Euro consult/Darwish Consulting Engineers. Published by the Directorate General of the International Cooperation, The Netherlands.

USDA, Natural Resources Conservation, (2002). Soil Conservationists, Salinity Management Guide-Salt Management. Available at http:// www. Lanfixlabs. Com. au/papers/p47-mysteries.pdf. 


\title{
الملخص العربي
}

\section{كفاءة تحسين السماد العضوى والجبس لحخو اص أراضى مستصلحة حديثا ومتزرعه بمحصول بنجر

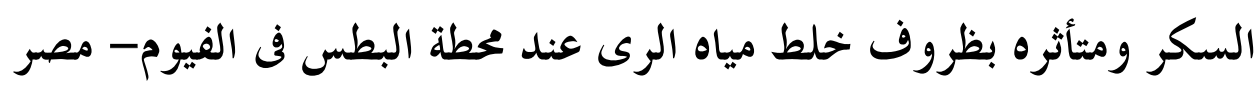

\author{
عبد الناصر أمين أحمد عبد الحفيظ
}

الكهربى، النسبة المئوية للصوديوم المتبادل. بجانب إنخفاض ملحوظ في النمو الخضرى ومحصول جذور بنجر السكر وقياسات جودةقا، آخذا في الإعتبار أن التغيرات في معظم هذه الخصائص وصلت إلى

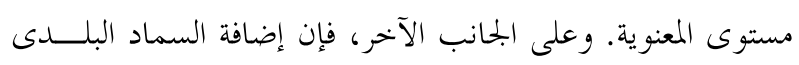

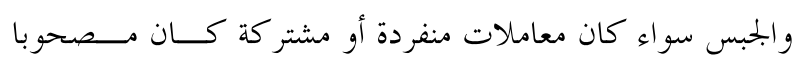
بتأثير محسن على كل من الخصائص السابق ذكرها سواء كانــتـ

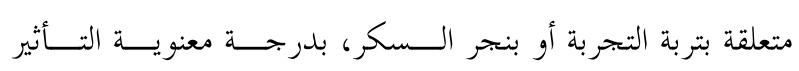
لمعاملات المشتر كة.

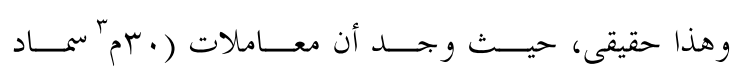

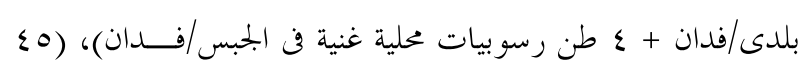

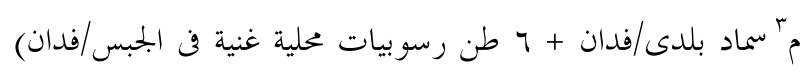

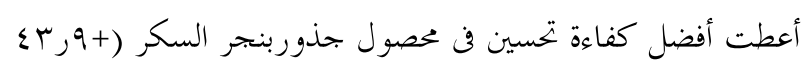

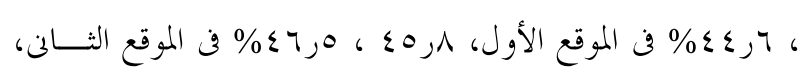

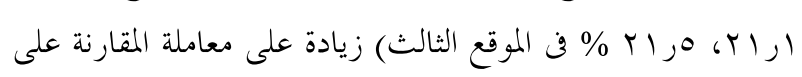
الترتيب، وأن هذه الزيادات في الخصائص المدروسة لكل من التربة

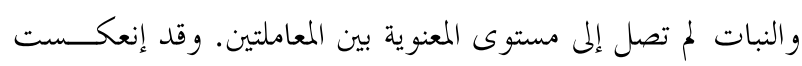

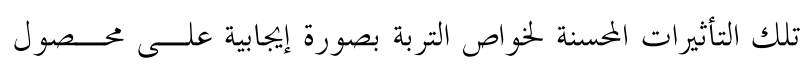
جذور نباتات بنجر السكر النامية وقياسات جودةا ولذا من الجدير

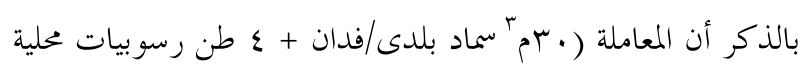

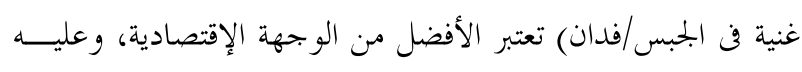

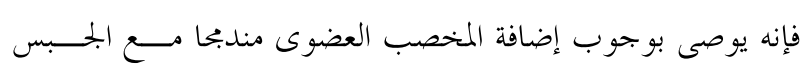

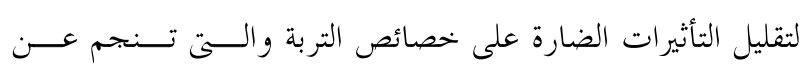

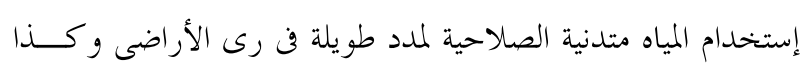
لتحقيق إستدامة لمحصول جذور بنجر السكر.
أجريت بتحبة حقلية خلال الموسم الزراعى هـ. . بT . . . r على ثلاث مواقع أراضى رملية طميية مستصلحة حديثا

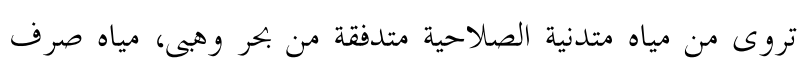

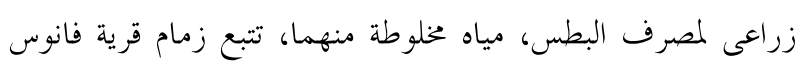

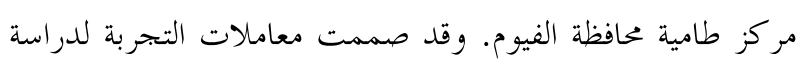
التأثيرات السلبية لإستخدام تلك المياه المتدنية الصلاحية على خو اص

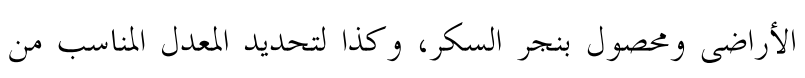
المخصب العضوى والذى يتكامل مع الجبس كمحسنات تربة لتقليل

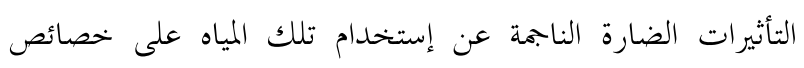
التربة ومحصول بنجر السكر وجودته. و كانت المعدلات المستخدمة

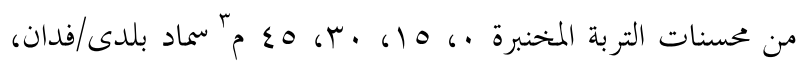

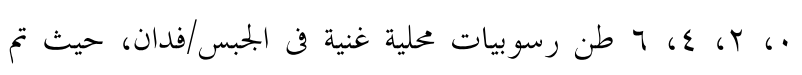
خلطهما بتربة قطع التجربة جيدا قبل زراعة البنجر، والذى تم تقليع وبتميع جذوره بعد ·1 ا يوما من الزراعة، وقد قدرت صفات

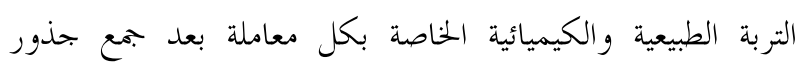
البنجر والتى تم تقدير محصولها وتحديد درجة جودةما. وأوضحت النتائج المتحصل عليها أن الإستخدام قصير المدى

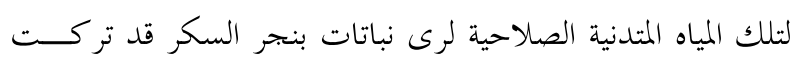

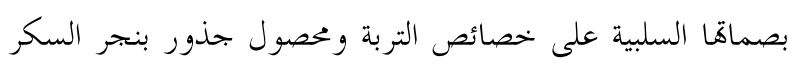
وقياسات جودته تحت الدراسة، خاصة في حالة قطع التجربة المروية

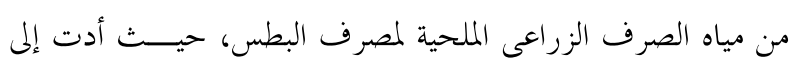
إنخفاض قيم الكثافة الظاهرية ، التوصيل الهيدروليكى، ومدى المــــاء

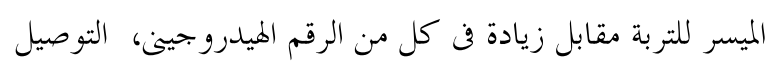

